\title{
COMPARISON OF REAL AND REVELATIVE WORKING AREAS IN ISLAMIC LAW
}

\author{
Syarifuddin \\ Faculty of Economics and Islamic Business \\ IAIN Palangka Raya \\ Email: syarif.adi@gmail.com
}

\begin{abstract}
One of the human potentials that is very valuable as well as distinguishes it from other creatures is reason. The messages of Allah, both expressed through the redaction of His revelation in the Koran and implied in His creation, can be revealed by reason, so that the purpose of law (Maqashid al-Sharia) contained in it can be known and manifested in life real. The use of reason in the area of legal work, let alone to determine or stipulate a law, became a long debate for Islamic thinkers after the Prophet Muhammad died. Even though they agree that the third source of Islamic law is reason (al-Ra'yu) but in their ijtihad the mujtahids use reason in different portions and methods. Some use it very large, and some are very small portions. In general, the jurisdiction can be distinguished in the form of atTa'abbud, namely the legal area which is the right of Allah (haqqullah) and at-Ta'aqqul, namely the legal area which is the right of Insan (haqqul Ibad / insan /) to think about it. In the latter area it is the authority of reason.
\end{abstract}

Keywords: Intellect, revelation, taaqquli and ta‘abbudi;

\section{A. INTRODUCTION}

The discourse on the position of reason towards revelation (religion) is often debated, sometimes paralleled and even contradicted one another. The conquest of human reason under religious autonomy reached its climax in the Middle Ages, when the orthodox Christian church waged the longest and most bitter war against science (Hodbhoy, $1996: 56)$. In the history of Islamic thought, there was an era of blind taqlid where the use of ijtihad reasoning was forbidden. This condition was accompanied by the proliferation of asceticism which tended to ignore the real dimensions of the real world and put forward the realities of the metaphysical nature (Yazid, $2007: 46$ ). On the other hand, in modern times, rationalism has become the foundation of anthropocentric sciences as the antithesis of medieval theocentric philosophy. A society that maintains religious beliefs and truths is considered a non-rational society that is naïve and subjective (Mujahidin, $2013: 43$ ). Religion must be in the private sphere and should not be displayed in the public sphere because it will damage the social order due to considerations of religious irrationality (Fanani, 2008 : xvii). As a result, the roles of reason and religion do not go straight and sometimes one of them becomes isolated from the daily life of society.

Currently the two great powers are in a dilemma. The dilemma faced by both of them is something that arises from itself, namely science. Science, at this time has been at the peak of its glory. This can be seen how science has become the prima donna in the modern scientific field. Religion which is human belief in dealing with God debates the truth of philosophy and science. Meanwhile, philosophy that claims to be the mother of science also debates whether science is something separate or something in common with itself (philosophy). And in the end, in addition to the struggle between religion and philosophy, there was also a fight between religion-philosophy and science (Mahfud, $2019: 3$ ).

In the current era, many people call it the era of religious awakening with a more rational performance. Because religion according to Talal Asad in the late 20th and early 21st centuries actually shows its existence in making changes to the world order both in politics, social and even economics (Fanani, 2008 : xvii). Therefore, the authority of revelation must be married to the interpretation of reason in the 
context of self-actualization in responding to everyday human problems. Because of that, the link between the text of revelation and human reasoning becomes very interesting, interpreted theologically to reflect the external values of sacred teachings into the reality of everyday life (Yazid, $2007: 47$ ).

Conceptually, revelation and reason are two intensities that actually need not be diametrically contradicted. Revelation as divine guidance is revealed to be none other than to guide the human mind entity towards the right path according to God's signs. On the other hand, reason was created by God as mi yar (benchmarks) in determining good and bad, holy or unclean, maslahat or mafsadat. At least this view refers to the philosophy of Islamic law which emphasizes that revelation is sent to bring benefit and prevent damage (Yazid, $2007: 46$ ), organize individual and collective life in order to achieve true happiness in the world and in the hereafter (Gulen, 2002 85) \& (Muslehudin, 1997 : 77).

Intellect occupies an important position in Islamic law, because it is a tool for understanding the laws contained in Islamic teachings, and even the law will be applied only to those who have reason. The great attention of Islam to human reason can be found in several editors of verses that instruct people to think, as mentioned in the Koran such as: afalaa tatafakkarun means whether you don't think (Surah. Al-An am: 50), afalaa tubshirun means do you not pay attention (Surah Adz-Dzariyat: 21), and many other similar expressions which show that the Koran pays special attention to the use of reason, even the ushuliyyin place it in a respectable position in the stratification of 5 main points which must be guarded or maintained (Al-Dharuriyyatu al-Khamsah), namely religion, soul, mind, descent and property. These five things are al-Gazali which are the main essence of what is meant by maslahat (AlGhazali, 1983 : 286-287).

The maintenance of the five main joints is ordered according to the priority scale. This means that the joints that are in the first place (religion) are more important than the second joints (soul), the second are more important than the third joints and so on (A. Kato, 2016: 116). This means that humans are special because of their intellect. Because reason in Islam is a place to accept obligations. Therefore, anything that can eliminate reason is a big crime and deserves punishment (Al-Qardhawy, n.d. : 493).

But the problem is whether reason also enters the working area of the shari'ah? Is he also involved in establishing the law. This issue is tried to be raised in this paper with a formula to what extent the authority of reason in understanding sharia law, is it just understanding or even to the level of stipulating law.

\section{B. RESEARCH METHODS}

The type of research method chosen is descriptive analysis,as for the understanding of the analytical descriptive method according to (Sugiono: 2009; 29) is a method that serves to describe or give an overview of the object under study through data or samples that have been collected as is without conducting analysis and making conclusions that applies to the public.

\section{RESULTS AND DISCUSSION}

As explained above, the position of reason towards revelation is in debate. Although reason and revelation can be put in a position opposite each other, the history of religious thought shows another reality. The two entities are often debated and even opposed to one another. There is a serious debate in the study of Islamic philosophy and Islamic theology regarding the composition of the two in an effort to emerge a variety of legal provisions that must be appreciated by every Muslim. At least like Muktazilah and Asy'ariah in addressing the intervention of human reason in the process of forming God's provisions for the good of mankind on this earth. In fact, not only Muktazilah vis a vis Asy'ariah 
has enlivened the debate exchanges, but also other factions such as the Maturidiyah, salaf schools and other ushuliyyin scholars have also enlivened the discourse on how to idealize the composition of reason and revelation in responding to God's commandment against His servants as illustrated below (Yazid, $2007:$ 46).

\section{a. Mu'tazilah opinion}

This group puts reason in a very superior position. According to him, God's commandment must have concrete implications for the life structure and life of servants in the world. In other words, God's actions must have the aim of building the benefit of mankind in their daily lives. For Muktazilah God is a very wise figure so that He must have virtue in creating humans. Without having a clear purpose, God created something in vain. This form of futility cannot be carried out by the Most wise Being. In short, God must be obligated to do good to mankind, common sense assumes this (Nasution, 1986 : 79).

\section{b. Ashariyyah opinion}

The opinion of this sect has similarities with Islamic philosophers. The orders and actions of God according to this school do not have to have a specific purpose such as for the benefit of the servant. God's actions cannot be associated with specific purposes and purposes, but instead God acts according to His will without requiring certain legal implications. The real impact of the law cannot be avoided from the form of God's actions and deeds, but comes naturally without having to be associated with God's deeds. In short, the Lord's will and decree has no illat for the realization of certain positive or negative goals or pretensions. According to the dominant view of this school, it is God who creates the causes for something to happen so that God's actions cannot be circumvented by certain causes or purposes (Yazid, $2007:$ 53).

\section{c. Maturidiyah opinion}

The Maturidiyah school puts reason in a strategic position even though it is not as big as the role given by Muktazilah. According to this school, God's orders and actions can be associated with various wisdoms and benefits for mankind on earth. They give examples of criminal punishment in religious teachings which have nothing but the aim of preserving the benefit of mankind. Other evidence that they put forward the arguments of the Quran such as the purpose of the creation of jinn and humans (QS. Al-Dzariyat \{51\}: 56), the legal stipulation for the Children of Israel (QS. Maidah \{5\}: 32) and the story of Zaid's divorce (QS. Al- Ahzab \{33\}: 37) The example of these three verses clearly states the connection between law and 'illat (reason), the wisdom and purpose of teaching a teaching. On this basis God's commandment can actually be linked to the benefit of mankind. Because God sent several messengers to give guidance to mankind, otherwise it would be useless for God to send His prophets. However, according to this group, the goal of benefit is not a necessity for God, on the contrary, God's commandments are indeed related to the benefit of His servants (Yazid, $2007: 50$ ).

\section{d. Salaf flow opinion}

According to the salaf school, God with a wise nature (al-Hakim) attached to Him always associates all His commands and actions with wisdom and praiseworthy goals. Wisdom for this flow is God's foothold in all His actions and deeds. Unlike Ash-Ariyah, who considers wisdom as the logical impact of God's actions. This Salaf sect positions wisdom as a form of initial goal in all God's orders and actions. Like Maturidiyah, this sect links all forms of action of God's deeds with specific goals. As the basis for their understanding is the existence of a causal relationship in the creation of heaven and earth (QS. AtThalaq $\{65\}$ : 12), the sending of the apostles (QS. An-Nisa $\{4\}:$ ) all of which are projected for the purposes of certain. Thus God's purpose for taking care of His actions is not merely a side effect of prior accident. On this basis denying wisdom in every act of God is a methodologically weak opinion (Yazid, $2007:$ 51). 


\section{e. Opinion Among Philosophers}

Islamic philosophers deny the existence of the connection (ta'lil) of God's deeds with certain goals. For this flow the orders and actions of God appear naturally without being created or willed in advance. They compared God's deeds to sunlight appearing naturally from the sun entity itself. Natural phenomena that occur everyday such as events of death, living, being smart, stupid, sick, healthy and so on are natural occurrences using the tenth mediator of reason. For this flow, the entity which has mandatory legal implications is only a single entity seen from its various dimensions. Thus, it cannot arise from something single except for a single thing. Something that appears is none other than the first sense (Yazid, 2007 : 52).

In this connection, the philosophers associate natural law phenomena with the tenth reason. On the other hand, they deny the effort and creation of a substance that has an obligatory value to exist. It is on this basis that they conclude that God's deeds cannot be associated with certain goals and pretensions. God with His superior position could not even be very naive to do something for the sake of the inferior under him. The perpetrator of an action is considered imperfect and less effective if the orders and actions are still associated with a purpose. God who has the perfect capacity with his single entity, the first and the last at the same time will have no particular pretension in all his actions. On the other hand, it is the very form of God that can be captured as pretension as well as as the doer and maker of everything. In short, God cannot be associated with a specific purpose because God's actions will be effective if they do not have any purpose. If God does something with a specific purpose, it means that God's entity is not yet perfect (Yazid, $2007: 52$ ).

As the debate of the scholars of kalam above, Islamic jurists are no less fierce in arguing in placing the portion and position of reason in determining Islamic law. Among the imams of schools such as the Imam Hanafi School of Figh more use ratio (reason) than hadith so that this group is known as ahlu ra'yi, as a comparison of the ahlu al-hadith group, which is a term for those who use hadith more than reason (As-Sayis, 2003 : 111). However, there are also scholars who oppose the use of ratio or qiyas as a legal proposition such as Imam Ibn Hazm, a well-known fuqaha who understands the argument simply by means of zahir nash and strongly rejects reasoning with the 'illat and qiyas methods. According to him, the texts of the al-quran and hadith are perfect and complete, so looking for 'illat or making an analogy is unnecessary (Ad-Dahiri, n.d. : 515).

In history it can be seen how the fluctuation and intensity of the use of reason and revelation by the mujtahid (imam mazhab), for example:

Caption:

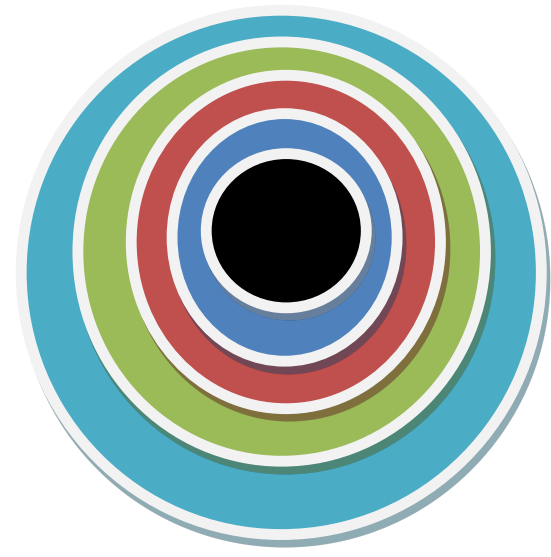

The innermost circle (black) is the group that uses the ra'yi the least. The principles they use in making laws do not justify the use of reason. Their rule is: La ra'ya fi al-din, ratio has no place in religion. This 
school is adhered to by Imam Dawud Zhahiri, but whether he realizes it or not, this school actually also uses ratio, only the intensity is very little.

The second circle (light blue) is a school that uses the ratio more intensely than the first group. This school was pioneered by Imam Ahmad ibn Hambal. Their doctrine states that the hadith of dhaif should be prioritized over reason.

The third circle (red) was initiated by Imam Malik. Its doctrine states that the ratio must be considered in order to consider benefit. Their rule is maslahah al-mursalah.

The fourth circle (green) is the Syafi'i school that he pioneered. In the process of making the law, this school uses analogies or qiyas.

Meanwhile, the last group in the fifth circle (light blue) is a school with more frequency of use of reason than hadith. This school was pioneered by Imam Hanafi. The explanation above shows the varying intensity of the use of reason by scholars in establishing a law through the ijtihad method.

This division pattern is just a classification for naming. Because in reality, ahlu ra'yi does not mean completely ignoring the hadiths, and conversely, ahlu al-hadith does not mean completely abandoning ra'yi (reason). However, from these two patterns it can be seen the emergence of different methods in legal istinbath but still based on the formulation of Muadz's ijtihad. Such as al-ijma, al-qiyas, almaslahah, al-istihsan, al-Syar'u man qablana, qaulu al-shahabi, saddu al-dzara'i, al-Urf, al-madinah and al-Istishab. According to Jasser Audah, all of this is based on the argument of the nas (naqal). This means that the difference between passages and these sources is the difference between linguistic propositions and rational propositions, but both are based on passages (Audah, 2015 : 154-179). Long before that Ash-Syathibi had included ijma, al-Syar'u man qablana, qaulu al-shahabi in the category of naqli arguments that were not in line with other arguments. There is no argument from him that explains this, but according to Duski there is a strong suspicion that the reasons are: For ljma, because of its status that has been agreed upon by the mutaqaddimin scholars, it is considered valid to be judged as a legal basis, not seeing the aspects of its formation process, while qaulu al -shahabi, is the material that was passed on to them from the teachings of the Prophet. This can be seen from the analysis of qaulu al-Shahabi as a part of the sunnah. Meanwhile, al-Syar'u man qablana, is because it has been listed in the Koran (Ibrahim, $2008: 83$ ).

\section{f. Combining reason with revelation}

Regarding the position of reason and revelation that sometimes collide, Ibn Taymiah gave a special attention that emphatically blamed those who rejected the role of reason at all, from the followers of the figh schools, philosophers and theologians. In this case, he wrote a book with the title Muwafaqah shahih al-manqul li sharih al-ma'qul, which is according to the authentic Naql with a strong sense or also called Dar Ta'arudh al-'aql wa an-Naql (dismissing the contradiction between reason and naql). In this book, Ibn Tay Scientific provides guidelines that must be considered when there is a conflict between reason and revelation (Syarif, $2017: 64$ ).

Al-Syathibi, one of the ushul experts in Granada, acknowledged the large role of reason in understanding syari'at arguments. In this case he applies three kinds of propositions, one of which is the argument for reason, while the other two are the argument for adat (a'diyat) and the argument for the text of the Koran and al-Sunnah which is called the argument of sam'iyat. first aligned by it, and divided into obligatory, impossible, and jaiz (permissible). The difference between the two is that the proposition of reason is theoretical, while the proposition of adat is empirical, but both are rational. The 
validity of reason is tested in terms of whether it is true or not, while customary arguments are tested in terms of reality and unreality (Al-Syatibi, n.d. : 34).

Furthermore, as-Syathibi states that the law of reason can bring certainty, as the arguments for the syari'at contained in the al-Qur'an and al-Hadith, if formulated on the basis of these arguments. The two sources also cannot achieve a degree of certainty if each is partially independent. Thus, both textual syari'at and rational arguments will achieve their respective certainties if one another supports each other. Intellect cannot be a proof of syari'at independently, because no matter how great its ability, reason cannot function as an argument that creates shari'at (al-'Aqlu lays bi syari ') (Haq, 2000 : 125).

Therefore, in essence, the driving force for the establishment of a syara law is to seek benefits and reject harm to humans. This driving force is the goal in establishing law, which is commonly referred to as the wisdom of a law. The wisdom of some laws can be in the form of vague cases, it can also be guesswork, and it can also be clear cases. The wisdom of this clear form is called illat by ushul scholars. Illat is the basis for guidance and research whether or not a law exists. This means that the syari'at exists when the illat is present and the syari'at does not exist if the illat is not present (Yahya \& Fathurrahman, $1986: 83$ ).

Among ushul experts there are those who distinguish between illat and cause. The difference is that cause is a sign that informs the existence of a law such as the slipping of the sun which is a sign that informs prayer, while 'illat is a matter, which is why a legal decision is manifested. So, 'illat is the cause of legal requirements, not because of the existence of law, so' illat is a legal argument. If the relationship between illat and law can be thought of with reason, then it is called illat and at the same time cause. However, both of them can be used as a basis for developing or establishing laws (Yahya \& Fathurrahman, $1986: 86$ ). Apart from the views that distinguish the two as above, it is clear that every law must have an illat or cause. Illat or cause can also take the form of something that human reason cannot think about.

Based on the difference in the form of illat or this reason, the ulama ushul fiqh divide Islamic law into two parts, namely: Islamic law which is at-ta'abbudi and Islamic law which is at-ta'aqquli or ma'qul ma'na (Yahya \& Fathurrahman, 1986 : 86). The division of Islamic law is the first type of law whose illat is known only to Allah himself and there is no way to know the illat. Whereas for the second type is the law whose illat is not specifically known only by Allah alone, but Allah gives guidance to reason to know its illat (Zahrah, $1958: 233)$.

From another aspect, As-Syathibi explained that for the benefit of life in the world, syari'at is built on two things, namely, first, the obligation of the servant to be grateful for the blessings given by Allah, second, the opportunity to feel the delights of all these blessings. For him, being grateful for Allah's blessings means taking advantage of everything that Allah enjoys according to His good pleasure as a source of blessings. Gratitude for that blessing is the right of Allah over humans, while the human right from that gratitude is a prosperous and prosperous life in the world, reward in the hereafter and freedom from the torments of hell (Haq, $2000: 137)$.

It is in the context of the realization of the obligation to be grateful and the right to enjoyment that in turn gives birth to what is called ibadat and adat (muamalat). Worship, because it is the right of Allah over humans, its meaning is the right of Allah. Therefore, reason is not given the authority to enjoy it. Thus the law in this field is ta'abbud. Whereas custom (muamalat), because it is a slave's right to the pleasures given by Allah, then to know and think about its meaning becomes a human right. Thus the law in this matter is ta'aqqul (Haq, $2000: 137$ ). 
In the context of the realization of the obligation to be grateful and the right to enjoyment, it is what in turn gives birth to what is called ibadat and adat (muamalat). Worship because it is the right of Allah over humans, its meaning is the right of Allah. Therefore, reason is not given the authority to enjoy it. Thus the law in this field is ta'abbud. Whereas custom (muamalat) because it is the right of the slave to the pleasures given by Allah, so to know and think about its meaning is a human right. Thus the law in this matter is ta'aqqul (Haq, $2000: 137$ ).

\section{g. Laws that are ta'abbud and ta'aqqul}

The word ta'abbud is a masdar form of the word ta'abbada which means tanassuk and tazallul, which is to submit and serve (Ibnu Manzur, n.d. : 2778). The word ta'abbud means the law which demands absolute obedience and obedience from every mukallaf to perform worship to God. Therefore, according to TM. Hasbi As-Shiddiqy, this law must be followed without the need to investigate its meaning and meaning (as-Shiddiqy, $1993: 22$ ).

The need for submission, obedience and obedience is not because it is prohibited to question and trace the basis of the legal provision, but because the texts which refer to the existence of these laws are not accompanied by illat or clear causes, and reason cannot with certainty know what is. become illat or because of the law. Therefore, worship is pure ta'abbud, or which is related to mahdah worship $(100 \%)$, especially worship material whose meaning (ideas and concepts) contained in it cannot be reasoned, then humans must accept whatever is stipulated by shari'a. at. If it is permissible to reason with reason, that only concerns its implementation. That is, if any law that the mind cannot know or reason with certainty about what is illat or the cause of the law, then it is a law that is ta'abbud.

The practice of worship that is different from the procedures prescribed by the syari'at is no longer ibadat. Shari'at limitations regarding thaharah and prayer, for example, absolutely must be obeyed without first thinking about why this is the way it is and why it is ordered. Intellect must not question why tayammum, which according to the eye does not mean cleanliness, can be a substitute for ablution and bathing for purification. But all that can be understood from matters of worship is obedience to God's commands, humble oneself to Him and exalt Him. Obedience is what becomes illat (cause) for the ordering of worship, nothing more or less than that (Haq, $2000: 137$ ).

In terms of benefit, the orders or prohibitions given by Allah SWT to His servants contain benefits, both individually and for the community. In terms of whether the benefit of a particular burden is only felt by individuals or the general public, then there is a burden that belongs to the servant (haqqul 'ibad) and some is the right of Allah (haqqullah) or the right of the community (haqqul mujtama) (Yahya \& Fathurrahman, $1986: 362$ ) and among the burdens there is a sense that can understand the meaning. An example of the five daily prayers that must be said on time. Some of the immediate benefits that seem clear are self-discipline and discipline, stability of faith and community. The way of prayer is taught for definitive reasons. The virtues of washing certain body parts before worship also contain health and other benefits. Zakat makes a significant contribution to maintaining responsibility and balance between the rich and the poor. Fasting has many undeniable benefits. Another example is the death penalty in Islam (when applied by a God-conscious ruler) if it is studied based on the senses and senses, leading to surrender to the Most Wise and Almighty (Gulen, $2002: 58$ ).

Regarding Hajj, in the Qur'an: And doing Hajj is obligatory for humans because Allah is for those who are able to travel to Baitullah (Surah 3: 97). Obeying this commandment is an act of surrender that leads to the experience of the haj, and contemplates its benefits as a world conference for Muslims, an opportunity for Muslims to come together for the sake of Allah and free from all human beings, from artificial discrimination based on race, sex, color, or rank. education. Whether it starts from the act of surrendering and using the senses and reason or using the senses and reason and then leads to 
surrender, Islam justifies it, because Islam is based on reason, senses and submission (Gulen, 2002 : $58)$.

In this case, as-Syathibi divides these rights into three types, namely:

1. Actions in which there is only the right of Allah, which in itself is pure ta'abbud, namely all worship.

2. Actions in which there are the rights of Allah and the rights of servants together, but the weight of God's rights is greater. For example, regarding the maintenance of the soul, although survival is a human right, this right is actually in the hands of Allah, so that no one is allowed by the shari'ah to take away his right of life by committing suicide or surrendering himself to be killed.

3. Jarimah (criminal) qishash for people who kill intentionally, this Jarimah qishash is viewed from the point of view that it contains the maintenance of the benefit of society. Because it is the right of Allah. Whereas if it is viewed from the point of view that it can extinguish the fire of anger and heal a heart that wants to take revenge, it is a benefit for the individual, because it is the right of the person affected by the disaster. However, the latter aspect is stronger. Therefore, the murderer is not sentenced to qishash if it is not prosecuted by the victim's guardian. The guardian can exercise his rights and can also completely forgive the killer (Yahya \& Fathurrahman, 1986 : 367).

Apart from the three types of rights above, there are also scholars who add one more right, namely the pure servant's right which includes material rights and rights related to materialism, for example receiving compensation for goods damaged, receiving the price of goods sold and etc (Yahya \& Fathurrahman, $1986: 367)$. From the description of the ta'abbud law above, it can be seen that in the field of worship, syari'at comes to function as a maker and creator of law (mubtadi and munsyi). This function is inherent in the law that is ta'abbud because there is no sense in determining the law of acts of worship before the coming of the syari'at. Before the arrival of Islamic law, people were allowed only to adhere to the previous syari'ah in carrying out worship, and after the arrival of Islamic law, they were no longer allowed to practice other ways of worship other than those outlined by Islam (Haq, 2000 : 140). Thus, reason is not given a role here because the right to impose law is the right of Allah, by which all laws in this form of worship are ta'abbud.

The word al-ta'aqqul comes from the word ta'aqqula which means takallafa al-aql, which means burdening the mind (Ar-Razi, 1987 : 488) which means law that allows reason to think about illat and its legal provisions. The openness of law that is ta'aqqul to be considered by reason is none other than to provide the possibility for humans to reap benefits from Allah's laws. This is in accordance with the purpose of the law itself, namely to provide as much benefit as possible and to avoid the smallest possible harm.

As for the law that is ta'aqqul in nature, it concerns customary issues (mu'amalat) and contains only a small amount of ta'abbud, namely laws that are established to formulate and regulate individual relations and community relations, or to realize the benefit of servants in the world. The meaning of this law can be understood and always paid attention to the letters and benefits, and can change according to changes in time, place and situation. Therefore, most of these laws are whole (kulliyat) in the form of general principles and are accompanied by their illat (as-Shiddiqy, $1993: 22$ ) such as marriage, before the shari'ah came, humans had already carried out marriage, then the elements The ta'abbud is that there must be a dowry, no matter what. Based on the above limitations, it can be understood that this customary field (mu'amalat) is essentially a law that is ta'aqqul, that is, reason is given the opportunity to know illat and determine its laws in order to realize the benefit of humans.

This openness of customary law (mu'amalat), in addition to the fact that the texts that govern this issue are given in the form of kully, these texts are also accompanied by their clear illat. So that reason can function to know and determine its own laws. However, what is more important is that in this customary 
law (mu'amalat), Allah SWT has given the right of legal imposition to the servant. Therefore, according to as-Syathibi, in the matter of adat (mu'amalat), because the meaning is already known by reason, then syari'at is only a complement (mutammimat).

The arrival of syari'at as a complement in this matter of adat (mu'amalat), apart from providing detailed knowledge about the benefit of humans, it also gives ta'abbud value to adat (mu'amalat). So that every muamalah is not only worldly, even though the ta'aqqul value in it remains dominant. The ta'abbud values contained in muamalah, even though they are few and not dominant, must be obeyed by humans, as they fulfill the ta'abbud which is fully contained in worship. In this case the syari'at intends to bring about benefits that are sometimes not understood by humans, therefore, reason must justify it and accept it happily, even though it cannot be understood. For example, iddah for a woman whose husband bullies her. Even though this iddah is the right of the ex-husband, the right holder cannot abort his right or transfer it to another man to marry his ex-wife in an iddah state.

In short, in the law regarding adat (mu'amalat) there is the right of Allah which is ta'abbud which must be obeyed as obedience to Him. This ta'abbud element is given by the syari'at which comes as mutammimah, and with this element muamalah also has the value of worship to Allah, and because of that people will also get the reward from every mu'amalah they do (Haq, $2000: 141-143$ ).

\section{CONCLUSSION}

From the description above, several conclusions can be drawn:

Based on the explanation above, it is true that the function of reason cannot be considered simple or insignificant, it will occupy an honorable position in the framework of finding illat or wisdom of a law to achieve the purpose of forming this law by referring to the main sources, namely the Al-Quran and hadith. A law is ta'abbud, if illat or the cause of the law cannot be known by reason, and it is a law whose legal imposition is the right of Allah. On the other hand, a law is considered ta'aqqul, if illat or the cause of the law can be thought of by reason, and it is a legal burden that is the right of the servant. Law in the field of worship is basically ta'abbud, because the legal provisions in this worship are the right of Allah, and illat or because the law is not known by reason with certainty. Therefore, the syari'at comes as a maker and creator of law (mubtadi and munsyi). Law in the field of muamalah is basically ta'aqqul, because the legal provisions are the right of the servant. It's just that if there are provisions in the syari'at, then reason must comply with the provisions of the existing syari'at. Therefore syari'at comes as a complement to provide detailed knowledge about maslahat, and at the same time as a value giver at-ta'abbud to adat (mu'amalat).

\section{References}

Ad-Dahiri, I. H. (n.d.). Al-Ihkam fi Ushul al Ahkam. Dar Al Kutub al IImiyah.

Al-Ghazali. (1983). Al-Musytashfa fi ilm al-Ushul. Dar-al Kitab al-IImiyah.

Al-Qardhawy, Y. (n.d.). Legalitas Politik: Dinamika Perspektif Nash dan Asy-Syariah,. Pustaka Setia.

Al-Syatibi. (n.d.). Al Muwafaqat Matba'ah al Maktabah al Tijariyah. Kutub IImiyah.

Ar-Razi, M. Z. (1987). Mukhtar al-Shihah. Maktabah Thaibah.

as-Shiddiqy, TM. H. (1993). Pengantar Ilmu Fiqh. Bulan Bintang.

As-Sayis, M. A. (2003). Sejarah Fikih Islam. Pustaka Al-Kautsar.

Audah, J. (2015). Membumikan Hukum Islam Melalui Maqashid Syariah (Rosidin \& 'Ali Abd el-Mun'im, Trans.). PT Mizan Pustaka. 
Fanani, M. (2008). Membumikan Hukum Langit: Nasionalisasi Hukum Islam dan Islamisasi Hukum Nasional Pasca Reformasi. Tiara Kencana.

Gulen, M. F. (2002). Memadukan Akal dan Kalbu dalam Beriman. PT RajaGrafindo Persada.

Haq, H. (2000). Falsafah Ushul Fiqh. Yayasan Ahkam.

Hodbhoy, P. (1996). Ikhtiar Menegakkan Rasionalitas Antara Sains dan Ortodoksi Islam. IKAPI.

Ibnu Manzur. (n.d.). Lisan al-Arabi. Dar al-Ma`arif.

Ibrahim, D. (2008). Metode Penetapan Hukum Islam: Membongkar Konsep Metode al-Istiqra alMa 'nawi asy-Syathibi. Arruz.

Mahfud. (2019). Dialetika Agama dan Filsafat Sepanjang Sejarah. Jurnal Dialektika, 18 No. 1.

Mujahidin, A. (2013). Epistemologi Islam: Kedudukan Wahyu sebagai Sumber IImu. Jurnal Ulumuna, 17 No. 1.

Muslehudin, M. (1997). Filsafat Hukum Islam dan Pemikiran Orientalis. PT. Tiara Kencana Yogya.

Nasution, H. (1986). Teologi Islam Aliran-Aliran Sejarah: Analisa Perbandingan (5th ed.). UI Press.

Syarif, N. (2017). Filsafat Ilmu Perspektif Barat. Gema Insani Press.

Yahya, M., \& Fathurrahman. (1986). Dasar-Dasar Pembinaan Hukum Fikih Islam. PT. Al-Ma'arif.

Yazid, A. (2007). Nalar dan Wahyu, Interrelasi dalam Proses Pembentukan Syariat. Penerbit Erlangga.

Zahrah, A. (1958). Ushul Fiqhi. Darul Fikri al-Arabi. 